\title{
Political Discourse and Artistic Fiction in Utopian Reality Representation
}

\author{
Natalia V. Kovtun and Vadim V. Kovtun* \\ Siberian Federal University \\ 79 Svobodny, Krasnoyarsk, 660041, Russia
}

Received 20.01.2015, received in revised form 17.02.2015, accepted 22.04.2015

\begin{abstract}
In Russian and Western literary studies, the peculiarity of Russian culture is often considered through the prism of Utopia. This article discusses the formation of an utopian metagenre in Russian fiction, tracing a change in emphasis from the political discourse to artistic means, and, conversely, archetypes that distinguish utopian world-modelling in different cultural epochs. Perhaps there is no better term than "Utopia" to characterize modern literature, where the avant-garde Utopias anticipate global communist Utopia that was formalized in artistic creativity through the theory of socialist realism, which in the 1950-1960s was replaced by retrospective Utopia of "the villagers" in the diversity of author's variants and technocratic Utopias of the "youth prose". In this paradigm the place of postmodernism as a set of techniques used for opposing Utopian intentions is determined by the role of anti-Utopia.
\end{abstract}

Keywords: Utopia, anti-Utopia, utopian metagenre in Russian fiction, political discourse, utopian world-modelling.

DOI: 10.17516/1997-1370-2015-8-7-1325-1343

Research area: philology.

\section{Introduction}

The problem of studying fictional utopia and principles of utopian world-modelling remains one of the most important in the modern literary studies. Creators of classical utopias regarded text as an opportunity to represent their own ideas, when "fiction is necessary... only as an entertaining outline" (Morton, 1956, 117), a choice of the expression manner was dictated by the level of its entertaining and ranged from the methods of a tale to the form of a novel (Bellamy, 1893, 1-2). The form of utopia was highly influenced by historical conjuncture: in the 18th century it included a travelling (also undertaken in a dream) to an unknown land depicting a state of universal Law, in the 19th century it included an image of a technocratic civilization, in the 20th century it included the horrifying images of the future, stirred by the science-fiction techniques. Utopian thinking, the ways of its representation in text became the subject of analytical criticism only in the $20^{\text {th }}$ century.

The purpose of this article is to show how gradual shift of emphasis from the political discourse (Bourdieu, 1998) to plot and vice versa takes place in the history of utopian metagenre',

(C) Siberian Federal University. All rights reserved

* Corresponding author E-mail address: nkovtun@mail.ru 
and to identify archetypes that distinguish utopian world-modelling in different cultural epochs. Particular attention is paid to the literature of the $20^{\text {th }}$ century, where utopia and anti-utopia are the major types of creativity. The legitimacy of the set task is identified by the specific character of utopia as one of the basic ideas of human culture, related to the concepts that "denote the phenomena, equally characteristic to all the epochs, that allow to see the connection of times and succession of ideas", fundamental basics and time representations (Artem'eva, 2005, 480). In one of the recent theoretical works utopia is regarded as an analytical tool for the analysis of the contemporary culture at large, intensified by utopianism: "We can explore culture (in its broadest sense) for its utopian aspects, its expression of longing and fulfilment. The strength of this analytical definition is that it encourages the identification of an element that different cultural forms have in common, although in so doing, it may also at times gloss over important differences between them. If we start from here, it is evident that contemporary culture is saturated with utopianism, even (or especially) where there is no figurative representation of an alternative world" (Levitas, 2013, 5). In this paper we consider the notion of utopia utopia as a kind of analysis tool, which is essentially evaluative (in case of the content) and impartial (in case of the level of its realization).

The interest in utopia is intensified in the critical periods of civilization development, when a total revision of the dominant values takes place: "The search for a positive image of the future, if it is regarded as spiritual work, as absolutely inevitable in the crisis epochs, especially at our time of total critisism of the foundations of modern civilization" - says E. Chertkova (Chertkova, 1993, 81). At this time an artist comes forward with a project that is alternative to the present one. The authors of classical utopias hope that their works will serve to enlighten the sovereigns. F. Bacon wrote his book "for the good of the Dauphin", hoping to find a monarch capable to implement into ideas into life, with the same purpose J. Harrington wrote "Oceana". The utopian text of Count Mikhail M. Shcherbatov (A Journey to the Land of Ophyr, 1784), A. Radishchev (A Journey from St. Petersburg to Moscow, 1790), and those of the Decembrists can be considered as the tools of political rhetoric.

\section{Theoretical framework}

The most important principle of utopia creation is the method of absolutization, postulating the ideal as unconditional and creative, which often excludes the possibility of critical perception, including the creator and protagonist of utopia himself. K. Mannheim defines utopia as a category that describes "any thinking, stimulated not by reality, but by models and symbols". Utopian consciousness "turns away from anything that can shake its faith or paralyze its desire to change the order of things" (Mannheim, 1994, 41). "Non-textual reality" is transferred into the text of utopia according to the principle of conformity to the author's idea of "the best social order". The ideal, mastered in the language of fictional images influences the readers' minds, evoking a response. The unity of the fictional utopia is provided by the unity of aesthetic vision and artistic and philosophical intuition of its creator. It is connected to the messianic tones of utopia and its prophetic monologism.

A utopian text that models alternate reality, serves as a kind of mirror reflecting the evils of reality. The path, shown by an author reminds a maze, at the end of which glimmers the image of the "better future" or the "golden age" of the past, the movement through the maze is defined and "provided with signposts; and no matter how we 
tried to escape, we will return to the same place again and again" - this is the semiotic nature of utopia (Petrucciani, 1991, 112). Crossing the borders of the text, A. Petrucciani connects with the will of the author, who puts a dot, awakening-return of a character or willfulness of a reader who closed the book (ibid). Whatever challenges the traveler coped with on his way to the Promised Land, whatever lessons he learned from the experienced, Utopia escapes and the ideal can not be completely adjusted to the reality. Disappointment in the utopian perspective leads to different consequences: either the author himself revises relations with the reality (F.M. Dostoyevsky opposed the idea of Christian existentialism to the project of revolutionary transformation of the world) or comes to the establishment of the power of utter anti-world (anti-ideal), which antiutopia embodies: Y. Zamyatin's novel "We" is a reaction to the standardization of being that is sarcastically developed in the direction of the Russian Association of Proletarian Writers (Kazarkin 2001, 5). The project of an ideal society, represented in Utopia, and the image of the back side of being (not-being) that is represented in anti-utopia, are related to each other according to the principle of mirroring, and the reality remains between them.

In the literary studies of $20^{\text {th }}$ century Russia is often considered as the melting pot of different kinds of utopian ideas, in the first instance it experienced absolute dominance of the utopia of power: the Bolsheviks and the Masons (Webb, 1980), the Bolsheviks and the Old Believers (Etkind, 1998). For the characteristics of modern literature, perhaps, there is no more capacious term than "utopia", where the avant-garde utopia precedes the global communist utopia that matured in art through the theory of socialist realism, which in the 1960s was replaced by a retrospective utopia of "villagers" in the variety of author versions and technocratic utopias of the "youth prose". In this paradigm, the place of postmodernism as a set of practices of confrontation to the utopian intentions is defined by the role of anti-utopia.

The fall of the Russian history into the "utopian abysses" is often only identified by the experts; analysis of the underlying causes of this issue is limited to references to the authorities of F. Nietzsche, A. Schopenhauer and to the ideas of Western Enlightenment and the Renaissance. However, the genre (metagenre), as shown by M. Bakhtin, is not only an aesthetic category, but the field of value perception of the world, the main way of understanding reality. And it means that one should look for reasons to explain the mobilization of creative pathos of utopia in the history of the nation itself(Egorov, 2007). Mentality of the artist of the $20^{\text {th }}$ century was determined at the time when F. Nietzsche's thesis "God is dead" was proclaimed. The resulted "Twilight of the Gods" forced them to two consequences: construction of a new universe where the artist-demiurge takes over the vacant place of God, the Creator. Artist, the Demiurge takes over the vacant place of God, the Creator (Pavlova, 2004). Utopias become the messengers of political theories, the embodiment of hope, and their creators - participants in the political discourse. It is not by accident that many public figures are also the authors of utopias (from A. Bogdanov and A. Chayanov to the classics of socialist realism), and those who were not ready for such a radical spiritual restructuring, tried to keep the features of the Christian image of the world and man in their own creativity (creativity of the "villagers").

However, utopias, as shown by the latest research, quite often "arise in conservative periods of the life of society, in the atmosphere of social and political stagnation, when the real way of the world transformation are not visible" (Egorov, 1985, 257). In this respect, "post-thaw" 
period in Russia, the second half of the 1960s 1970s, creates a very fertile ground for the spread of utopian ideas: the conquests of the epoch of "cultural liberalization" in the country were destroyed and intellectuals go either underground or immigrate. The increased confrontation to the West actualizes the interest to "Russian", national. The revival of traditional values is considered as a variant of outcome, what is reflected in the "village prose". The development of this literature is largely determined from the start by the the political doctrines of the culture of socialist realism, the progressivist utopia of "the beautiful far away" is opposed to the utopia of " the radiant past" (Parthe, 2004).

Modern utopian projects are fundamentally different from the samples of the Age of Enlightenment. An author of the classical utopia, creating an image of another, the best of worlds, himself remained in the "old" world, in the tradition; a contemporary writer simply does not have this possibility, hence, the existential orientation and relative "modesty" of plans of the today's Nigdeya (the definition of T. More, who wrote about the "nowhere" island), its new hero is an individual who compassionates to the world, rather than a curious observer. The creators of classical utopias have never confused reality and text, history and fiction, in the $20^{\text {th }}$ century, on the contrary, it was the Russian utopia which was inclined to practical implementation of the due and offered an alternative political program, hence its new definition "tutopia" (Etkind, 2001). The definition of utopia as "now-here" is found in William Morris and Aldous Huxley's texts (in "Island" in particular) as a call.

\section{Intellectual and Peoples Lines of Metagenre Formation}

Before turning to the analysis of the principles of the utopian world-modelling in the texts of contemporary literature, a brief overview of the metagenre formation will be given. The reforms of Peter the Great, as well as Western European samples (the works by T. More, T. Campanella, F. Bacon, L.S. Mercier) influenced formation of the Russian utopian tradition (Rossi Varese, in $1982,7)$ - in the $19^{\text {th }}$ century the Russian elite is well aware of the classic texts that came to Russia with the Masonic literature, through which the codes of Enlightenment were understood. Freemasonry became one of the versions of the perfect projection-the utopia of self-improvement as the utopia of the ideal governance. For those, who after Peter's reforms lost faith in traditional values, Freemasonry opened the prospect of secret knowledge and, at the same time, gave the moral code that served as a guarantee of the moral elevation of personality. The first Utopians (A. Sumarokov, M. Kheraskov, M. Shcherbatov and V. Levshin) were in the Order themselves, the literary texts that they created had not only an artistic dimension.

A kind of alternative to the state utopianism (starting from Peter the Great utopian projection became one of the government functions) on the one hand, were the compositions of dreamersintellectuals (from the Masons, the Petrashevsky Circle, the George Sanders to the Westernizers and the Slavophiles), and on the other - mystical projects of the Old Believers, under the direct influence of which two main areas of Russian utopia: intellectual utopia and people's utopia, were formed.

People and religious line of utopia that was naturally linked to the Old Russian "walkings", "dreams" and "visions", made it possible to revise the classic model of the ideal in favour of the national tradition: images of mystical city Kitezh that is located over the last border of Belovodye (Chistov, 1967). In this case not the image of the perfect state and not ways of people's enlightenment, as in the lyrics of SaintSimon, Fourier, and Owen are important, but 
the yearn for immediate possession of the ideal and requirement of steady movement towards it. Reference utopian project - "Travelers" to "the earthly paradise" - came into the world from the Old Believers (the sect of "runners") and differed in fanaticism in the requirements for search of the righteous place, hidden from the outsiders. "The Travelers" were not considered within the boundaries of literature, on the contrary, they were perceived as authentic testimony left by those who actually reached the blessed land. In the literature of the $20^{\text {th }}$ century, the people utopism is relevant in the text by A. Novoselov "Belovodye" (1917) (Kovtun 2010, 133-144) and succeeding it works by the traditionalists, in the early works by A. Solzhenitsyn, "Lada" by V. Belov, the novel by B. Lichutin "Wanderers" and the stories by V. Rasputin. And, on the contrary, the rationalist image of "the blessed country" is marked by the western European canons, and national culture is often only the background that accentuates familiar sociopolitical constructs.

Genealogy of Russian intellectual utopia goes back to the work of the historian and publicist Prince M.M Shcherbatov "Journey of Mr. S .., a Swedish Nobleman to the Land of Ophir". The utopian writings by A. Sumarokov ("Dream: a Happy Society", 1759) and by M. Kheraskov ("Numa, or Flourishing Rome", 1768) that preceded it, were written with an emphasis on philosophical preferences of the authors and lie outside the philological tradition. Philosophicity and Masonic intentions are certainly characteristic to M.M. Shcherbatov's Utopia, but in this case the idea gets thoughtful artistic decoration (Vernadsky, 1917, 176-177). The utopian project is created as an alternative to the policy of Catherine and consolidates the values of pre-Petrine Russia, the image of the state-family, where "the power of the state is connected to the benefit for people" (Shcherbatov, 1896-1898, 101) and St. Petersburg as a stronghold of Western progressivist culture was forgotten.

It is known that utopia was of vivid interest to Decembrists, especially to M. Lunin and P. Pestel, the creator of one of the toughest projects of the "new Russia" (Semevsky, 1909, 208-210). The Silver Age philosophers not without reason believed that "the Decembrists were raised in the more or less mystical Masonic lodges" (Berdyaev, 1994, 221). The utopias of the latter (the utopias by A.D. Ulybyshev and V.K. Kuchelbecker) are considered by the authors as tools of political struggle. Decembrist movement finds its main form in discourse, in rhetorical device. According to Y.M. Lotman's observation: "It gave possibility- from the standpoint of the later norms and beliefs - to accuse the Decembrists of phrase-mongering and replacing words with deeds" (Lotman, 1994, 334), but it was the word conveying the high idea that was defined as a deed. Rhetorical culture allowed neutralizing the border between word and thought, text and meaning, "composition of text and construction of the perfect society (social text of utopia) are interrelated" within the frames of culture of the normative type (Kalinin, 2002, 6). The Decembrists' utopia finishes the Age of Enlightenment, in its tragic perspective the kingdom of "liberty, equality and fraternity" was broken on the scaffold. The price for implementation of utopian project in the history was named, but the attempts of reality transformation by the revolutionary means continued.

The novel by Prince M.M. Shcherbatov and the Decembrists' texts reveal a range of archetypes characteristic of Russian utopian discourse of the Age of Enlightenment in general (Artem'eva, 2000, 16-17):

- The idea of statehood is good in its essence, but the right people should be chosen for its implementation. 
- Contemporary society is in crisis. The reason of crisis is a ruler's mistake, most often Peter the Great's.

- Further misfortunes can be avoided if the moral values of national culture are revived, a king, the philosopher surrounded by the enlightened (as dedicated) elite should be put at the helm of power.

- The model of the ideal society is quite obvious, it is based on the pre-Petrine tradition, utopia is devoid of speculation, characteristic of the European projects.

- Russian people are religious and kind by nature. These ideal qualities should be developed with the help a wise state structure.

- Russian past is sacred, it becomes a guarantee of the absolute future and the present is only preparation for it.

- Russia's execution of its messianic mission will also save Europe that lost its former spirituality.

\section{Fictionalization of utopia, its transformation into novel}

The process of utopia fictionalization, where presentation of the ideological conception is subjected to artistic logics is connected to the name of the author of "Eugene Onegin" (1823-1831). A.S. Pushkin of the postDecembrist age is devoid of utopian illusions of the predecessors and had to appeal to the authority of the government as the only support of the progressive ideas of the Enlightenment. Pushkin, the heir of the Enlightenment, is frankly afraid of Russian riot, "meaningless and merciless": "'The Captain's Daughter" was the parable-warning, anti-utopian in its essence" (Etkind, 2001, 50). Aestheticizing state, praising the greatness of Universal Law, the writer retains the right for spiritual emigration in creativity: "Pushkin was the great Russian utopian specifically because at the beginning of the $19^{\text {th }}$ century he turned out to be, perhaps, the most European of all the European writers. As more than convincingly proved by our merciless to man age, classical humanism that appeared in the Italy, was brilliant and grandiose utopia" (Hlodovsky, 1999, 314). The riot was excited by the means of aesthetics, embodied in verses, novel "Eugene Onegin" and poem "The Bronze Horseman" ... Pushkin heroes, like the sectarians, the "Runners" try to escape from the power of Leviathan. They go on a journey, madness, love, into their inner world - the only truly free place on earth.

In the famous novel an ironic image of the new Russia is presented. A.S. Pushkin transforms the world of serious alchemical experiments by the elements of artistic games. The poet puts pressure on the prophet. In the seventh chapter of "Eugene Onegin" utopia becomes the most important characteristic of a literary work: the image of the future is compared to the reality, duality of image appears and vision of the future becomes plastic, imaginative. The gap, which utopia leaves between today and tomorrow, using the method of "alienation", allows the poet to introduce the elements of satire on contemporary reality into the traditional "scheme". Description of the future is built on the contrast with the present up to details: "in 500 years from now" in Russia there will be highways, "cast iron bridge over the waters", wonderful tunnels, which were famous in Atlantis, but "now the roads are bad, / Forgotten bridges are rotting / Fleas and bedbugs at stations / Do not allow to sleep for a minute (Pushkin, 1986, 306). In his utopian sketch the writer is far from rationalism and economic and political doctrines of the predecessors, he is driven by a free flight of fancy. The image shadows the usual "scheme", depiction of the "wonderful future" is ironic, by 
far not absolute and open. The poet considers utopia in the context of pure art. Metagenre will be further developed in this way.

Artistic discoveries of A.S. Pushkin were continued in the utopian novels by F.V. Bulgarin "Probable Tall-Tales or Wandering around the World in the 29th Century" (1824); Improbable Tall-Tale, or Journey to the Center of the Earth" (1825) and Prince V.F. Odoevsky "The Year 4338. Petersburg Letters" (publication of the first excerpts in 1840). F.V. Bulgarin's texts are devoid of orientation to eternity, they turned into the novels, adorned as utopia. The author is engaged not only in the description of social and political system of the absolute state, but paradoxicality and entertaining aspect of its life and customs daily life. Utopia is devoid of orientation to eternity: Bulgarin does not aspire to instruct the descendant, for him it is important to give aesthetic pleasure to the modern audience, for which the writer, according his own words, was an "armorbearer and horseman" (Severnaia Pchela, 1851, 4). The future world is filled with vivid features and details, the theme of culture as a single text, which will become the main for the utopian creativity of the book by Prince V.F. Odoevsky, was declared here for the first time. Selection of "environment" for his novel "The Year 4338" was carried out not in terms of artistic entertaining, but quite seriously and carefully: "In Odoevsky's writing development of science and technology allows to solve social problems and give all people wealth and comfort" (Artem'ev, 2005, 480). A writer-prophet who replaced the recent jester/gaper returns to Utopia.

Mystic-technocratic utopia by Prince V.F. Odoevsky reflected the most important aspects of the author's conception of the future, which was influenced by the mystics who were popular in Russia: from J. Böhme to L. de SaintMartin and Portage. The novel remains true to the archetypes of the Masonic utopia: the text manifests the values of moral self-improvement, harmonious unity of the enlightened government and the people; developed the ideas of "Fourierist phalanx" and "living knowledge" (gnosis) are developed; images of Atlantis, the oracle are widely represented. The author offers the first poet-wiseman as the leader of the absolute state. It is already here the favorite form of the Russian literary utopia - the notes of a traveler around the beautiful world - was developing. The method of the "manuscript history" and diary entries is aimed at convincing the reader of the image authenticity.

\section{Decline of the "happy utopia"}

Debunking of the "happy utopia" is connected to the release of the novel by N.G. Chernyshevsky "What is to be Done?" (1863), long before the first announcement of antiutopia "We" (1921), as it is commonly believed (Mil'don, 2006, 277). "Vera Pavlovna's Fourth Dream" is a variant of traditional European utopia with crystal palaces, phalanxes, ideas of harmony of mental and physical labor, free love and pleasure. The origins of the story go back to "Feast" by Plato (Vaiskopf, 2003, 555). Chernyshevsky deliberately emphasizes the replication of the novel form, considers the text as a kind of social programme ("a textbook of life"), specifying the methods of its implementation as well. However, rationalization of myth and mystery leads to their parodying, theatricality, what was already perfectly understood by the contemporaries (Herzen writes to Ogarev: "He finishes by phalanx, brothels, without any hesitation" (Herzen, 1963, 167)), rigidly mocked Vladimir Nabokov in "The Gift". Utopian images in "What to be Done?" in many details go back to the reality that denies the canons of metagenre (Paperno, 1996, 157-160).

In the $1860 \mathrm{~s}$ of the $19^{\text {th }}$ century the first "heretical" versions of utopia appear. 
F.M.Dostoevsky in "Notes from the Underground" and M.E. Saltykov-Shchedrin in "The History of a Town" destroy the mechanical rhythm of utopia predetermining features of the new metagenre -anti-utopia.

In "The History of a Town" UgriumBurcheev, armed by the writing of "educator" Borodavkin, becomes the new organizer of the known "details". The author looks at Masonic myths through the eyes of a tough realist and phalanxes are easily transformed to barracks, reasonable discipline to drill. In the final of the fight of the "scoundrel" with live life, and the "scheme" with the history, "It" appears. This symbolic image has a lot of preferences in criticism. Traditionally, it is regarded either as "an allusion to the forthcoming spontaneous popular uprising" (Bushmin, 1980-1983, 663), or as the beginning of a new stage of the reaction. However, both interpretations are out of the line of utopia, the facts that can not be interpreted on the basis of the proposed concepts, remain. "It" is a metaphor of freed being. Fictitious, absurd story of Nepreklonsk is over, and, hereafter, it will be as Glupovsk dwellers will make it. In fact, the image decoding depends on their efforts. "It" is the emblem of tomorrow that can not be read in the system of the existing historical and cultural coordinates. The image of Utopia in SaltykovShchedrin's creativity is considered of as a part of history, but not the last one.

The very image of Ugrium-Burcheev who "conceived to capture the universe", replacing God, is traditionally compared by literary scholars with the figure of Arakcheev, but different version looks more convincing in the context of utopia. M.E. Saltykov-Shchedrin's character inherits, the one hand, national utopism of the Khlysts and the Skoptsy, with their general ideas of sacralisation of a spiritual leader, dissolution of the personal into the public, where already Z. Gippius could identify "certainly-Marxist formula" (Pushchin, 1908, 174), and on the other hand - the ideals of the famous terrorist of those years S.G. Nechayev. "The History of a Town" has the image of hypothetical Nechayev, who got the power and the ability to implement the plans of reconstructing the world (Svirsky, 1992). Political conspirator and adventurer Nechaev is a widely debated figure in the public circles of the 1870s, "Nechayev's trial and fiction appear as the equivalent factors" that influenced ideological choice of the youth of those years (Mogil'ner, 1999, 24). According to the confessions of some of them, Nechayev's example persuaded to agree with the thesis: "The end justifies the means" (Debagory-Mokrievich, 1989, 57-105), “The Story of a Town" is devoted to its refutation. "New people" by N. Chernyshevsky who were reflected in the mirror of M.E. Saltykov-Shchedrin's satire, turned into dictators and terrorists. Rakhmetov returned from America as Shigalev (Etkind, 2001, 85-90), and even F.M. Dostoevsky saw hooves and devil's horns under Napoleon's threecornered hat of Russian socialists.

In Dostoevsky's novels faith of classical Enlightenment in the natural goodness of man is debunked. Human nature is the main obstacle to building a perfect state. Man will always seek to "declare" self-will, but if he refuses, then he will admit the truth of the Grand Inquisitor, whose image is marked with the ideology of Freemasonry (Kasatkina, 1996, 57-65). The writer sees diabolical pride and temptation over the initiatives of the enlighteners-utopians. Dostoyevsky took materials of the Nechayev's case as the basis for the novel "Demons" (1871-1872). Images of young Verkhovensky (whose prototype was Nechayev), Stavrogin, Kirillov Shigalev and the children of utopian revolutionaries of the 1840 s are infernalized. Mangodness pretensions of the mortals lead them to spiritual bankruptcy: "The reality, which "Demons" simulate, is developed in such a way 
that it does not have any values: to the end of the novel it becomes axiologically empty" (Smirnov, 1994, 124). It is possible to take metaposition in this world when a person overcomes all the human in him/herself and, like Stavrogin, accomplishes the process of self-negation. It is the way that characters of A. Bogdanov's utopias develop and then model social-realistic literature, where the measure of approaching to the communist future is a degree of immorality and anti-humanity (in the ontological sense).

\section{Utopia as guidelines for action}

"The Philosophy of the Common Task" by $\mathrm{N}$. Fyodorov represents a fundamentally new type of utopian consciousness - "priestly". Before N. Fyodorov intellectual utopia developed either in the field of ideology (from A. Radishchev and the Decembrists to N.G. Chernyshevsky) or in the field of fiction (from A.S. Pushkin to F.M. Dostoyevsky). For the "Moscow Socrates" Utopia is a theurgic action, done personally. $\mathrm{N}$. Fyodorov retains interest in the traditional problems of utopia: gender issues, carnal love, progress and transformation of the moral nature of man. The idea of chastity, developed by the thinker is close to the religious practices of the extreme sectarians. It is not Eros that conquers death, but death that is intimately understood in the act of resurrection, conquers and dissolves the desire - the idea will be further developed in the literature of socialist realism, with its Gnostic ideals of androgyny and shamanic practices, up to vampirism, that were already significant in A. Bogdanov's utopias. Several other names, especially A. Bogdanov (pseudonym of Alexander Malinovsky) and I. Kremnev (pseudonym of Alexander Chayanov) are connected with the tradition of "positive" utopia.

The "Red Star" novel (1908) marks a change of the utopian tradition, which became indifferent to the moral aspects of the future.
Ideas and images of the novel reflect utopianreligious thought of the turn of the $19^{\text {th }}-20^{\text {th }}$ centuries in its materialistic incarnation, Masonic symbols (images of the pentagram, the third eye, Temple-phalanx; motives of prophecy, initiation and "brotherhood") bear serious ideological burden in the text. Bogdanov opposes the idea of social equality, embodies by the mystical means, to the teaching of moral enlightenment of man. His utopia ideally corresponds to the Western European criteria of metagenre: it is "all-embracing", rational and strictly regulated. The text of "Red Star" is constantly doubles, slips from the field of literature to mystery and esoteric action. The word becomes an instrument of reality transformation (Kovtun, Proskurin, Vasiliev, 2013, 129-140). The change of utopian orientation, fetishization of progress and technology overshadow man, making his presence external, not mandatory. A. Bogdanov was the first who deprived phalanxes of their traditional inhabitants - the intelligentsia that poorly responds to "cultivation" of ideas, and, in anticipation of the Bolshevik utopia, gives the hammer of master Hiram to the hands of an uneducated worker. Thus, a "prophet with the hummer", who was predicted as yet by Dostoevsky gets special powers in the real story.

The utopias by N. Fyodorov and A. Bogdanov sum up the moral and utopian tradition of Russian enlightenment. The utopian archetypes established in the Russian intellectual utopia since the time of Prince M.M. Shcherbatov, undergo serious changes in the novel by A. Bogdanov.

- Instead of demanding partial improvement of the existing order, its radical replacement by the communist regime is proposed.

- The artist-dictator stands at the helm of Utopia.

- The model of an ideal society incorporates the elements of the most ancient cultural 
codes: paganism, Gnosticism, mystical and shamanic practices.

- Russian people are the Messiah who brings the revelation of a new truth of communism to the world. It is the "theomachist" and "god-builders" people, by whose efforts utopia merges with reality, spiritual practice is superseded by the social one.

- The new Russia does not have analogues, either in the past or in the present; it is a replica of the future world, manifested in today.

- Socialist Russia is a post-apocalyptic phenomenon, the cult of death is intimately incident to it. Utopia is marked by eschatological symbolism.

- Russia's execution of its destined path makes it the center of world culture, the ideal state.

Thus, post-revolutionary literature, from the perspective of utopia, is characterized by the unity of the people's-religious and intellectual lines of metagenre formation. People crave to find the "better future" at the turn of decade, and in this case the price is not relevant. The state requires individuals to "sacrifice themselves". The new revolutionary society is built at the level of word, discourse and political slogan. By this time, two main lines of further development of metagenre were defined: "post-socialist" utopia by I. Kremnev "The Journey of my Brother Alexis to the Land of Peasant Utopia" (1920) and the famous anti-utopia by Y. Zamyatin "We" that summed up the utopian search of the turn of the $19^{\text {th }}-20^{\text {th }}$ centuries in general were published. The revolutionary methods of reality transformation and the consequences to which they led, generate deep disappointment among the intelligentsia. S. Frank defines this state as "a collapse of political fanaticism in general" (Frank, 1990, 126).
In a utopian novel by A. Chayanov traditions of educational utopia with fabulous context of folk utopic legends about the search for the mystical City of Kitezh and Belovodye are merged. The author distances himself from the legacy of the classics of social utopism "of the old Morris, virtuous Thomas, Bellamy, Blatchford", Fourier, Chernyshevsky, Herzen and Plekhanov (Chayanov, 1989, 163). The world of ideal peasant state is opposed to the socialist projects of the Sixtiers. Being an outstanding economist and co-operative figure of his time, A. Chayanov sincerely believed in the perspective of nature of the peasant economy. Thematically, vividly and emotionally the story by A. Chayanov turned out to be close to retrospective utopia of the late works by I. Bunin and utopian novel by General P. Krasnov "For Thistle" (1922). In the latter text, the ideal Russia is plunged into the atmosphere of the $16^{\text {th }}$ century, orthodoxy, patriarchy, monasteries, wooden peasant izbas and bells. The chosen space is separated from the rest of the world by thistle, which creates the illusion of abandonment of the ideal country and saves it from the harmful influence of progress. The works by A. Bogdanov and A. Chayanov create the samples of positive utopia, inherited by the Russian literature up to the end of the $20^{\text {th }}$ century.

Even a cursory analysis of the national utopian tradition formation suggests that utopia in Russia not only reflects certain aspects of the life of society, but acts as an instrument of political discourse. One of the reasons for this situation is literature centrism as the effect of "omnipresence" of literature that focused a lot of social practices on book and literary models (Crisis of Literature Centrism, 2014, 3). The peculiarity of Russian utopian tradition is most evident in terms of the cultural code underlying utopia. In a classic study by L. Mumford "The Story of Utopias" the author identifies two types 
of projects: the utopias of "escape" and utopia of "reconstruction" (Mumford, 1972, 15). An appeal to the inner world of man-creator and to the problem of shelter, where a person is saved from the cruel reality is characteristic of the first one; for the second one the interest is focused on the external world, attempts to recreate the material environment and the sphere of ideas. Up until the socialists and N.G. Chernyshevsky national utopian tradition cultivated moral reeducation of personality, gravitated toward utopia of "escape", after "Vera Pavlovna's Fourth Dream" the problem of radical restructuring of the world and natural human nature came to the fore, esotericism displaced traditional morals.

Russian utopian discourse differentiates between the complex interaction of the utopia of power (projects of Peter the Great, Catherine, Count Arakcheev and the Bolsheviks) with alternative utopias (intellectual and folk ones).

A brief phase of concerned inducement of utopian dreams (the Masons and Catherine, the masons and Alexander I, the Bolsheviks and the sectarians) is replaced by a phase of persecution and terror, when the official utopia gets rid of "competitors". Relative tolerance to the utopian dream and fragments, as well as cautious attitude towards independent utopian text that represent an improved model of the state is illustrative (Heller, Nike, 2003, 248-249). Catherine did not approve of the project by M.M. Shcherbatov, Lenin was resented by the ideas of "godbuilders". Interpenetration of ideas, themes and images of the "official" and "alternative" utopias (mythologemas of "Moscow - the Third Rome", the philosopher on the throne, the motives of isolationism, androgyny and Paradise) are characteristic; practices and artistic fiction, when power aggression towards other utopias are explained by the necessity to conceal the genetic affinity that is particularly noticeable at the level of the Bolshevik utopia formation.
From the perspective of the proposed ideal and methods of its implementation in the Russian literature of $18^{\text {th }}-$ early $20^{\text {th }}$ centuries there are Masonic (A. Sumarokov, M. Kheraskov, M.M. Shcherbatov, V. Levshin), Decembrist (V. Kiichelbecker A. Veltman, A. Ulybyshev), educational (A. Pushkin, F. Bulgarin), scientific and technocratic (V. Odoyevsky), socialist (A. Herzen, N. Ogarev, the Narodniks, $\mathrm{N}$. Chernyshevsky), religious and moral (N. Gogol, F. Dostoevsky, L. Tolstoy), creativetheurgical or "modernist" utopias (N. Fyodorov, K. Tsiolkovsky, K. Merezhkovsky, A. Bogdanov, A. Chayanov), which will be also joined by only briefly mentioned in this paper the utopia of "religious synthesis", recreated by the works of the Silver Age artists (Matich, 2008). "Godseeking" and "god-building" of this period form the chimeric type of consciousness and are indicative of the loss of whole world view that became one of the reasons for the future victory of the Bolsheviks utopia (Groys, 1993, 63).

\section{Global utopian projects and literature of the $20^{\text {th }}$ century}

Literature of the Soviet period became the voice of power, "a mean of the direct representation of power" (Dobrenko, 1993, 73), and can be considered as a single Utopia (which invariants are the texts of individual authors): "Soviet literature, apparently, is the only in its kind phenomenally interesting example of the literary utopia, literature as utopia", notes V.M. Akimov (Akimov, 1994, 15). The canon fixation took place at the beginning of the 1930s, and collapse in the "long 1970s". The Gnostic religion acted as one of the sources of utopian ideology. Gnosticism becomes the heritage of socialist utopia due to appeals to both Marxism and to the Masonic tradition that is closely connected to "the heritage of the world Gnosticism” (Sakharov, 2000, 17). Freemasonry influenced establishment of Russian intellectual 
utopia of the $18^{\text {th }}$ - early $20^{\text {th }}$ centuries. G. Mitin asserts the fundamental role of N. Bukharin, who was close to the Masons in formation of the Social Realism doctrine (Mitin, 1990, 26, 41). In complementary, with the respect to the power, literature of the 1920-1930s, creative-theurgical, Gnostic, with the cult of masochistic suffering and labor austerity Utopia of the proletariat-demiurge is established. Leveling boundaries between Utopia and reality and mass character of the truth perception became the distinctive features of the utopian tradition, the attributes of the demiurge, from an artist dictator, come over to a political leader (Kovtun, 2005, 118-319).

By the 1930s the utopian tradition is corrected. Spontaneous enthusiasm of the revolution was displaced by toughly regulated state politeness. Utopia merged with ideology. Alongside with the official utopia of churchstate, recreated in industrial novel (Clark, 2002), the utopia of "communal paradise" - a deflated version of house-commune, sacralized in the 1920 s, is formed in the literature of the mid-1930s (Goldstein, 1997, 128). Literature went back to the themes of family, love, food and comfort that were topical in the project by A. Chayanov. By the end of the 1940s utopia loses the most important generic features: global scale, "inclusiveness" and universalism. Canon reached the phase of self-parody.

In the relatively "quiet" periods of the canon functioning, gnostic moods that determined ideological, philosophical and aesthetic conception of social realism of the first half of the 1930s and the turn of the 1940-1950s are retouched. Post-revolutionary culture was born from the realization of previous failure of the Bolsheviks' claims to the immediate restructuring of the world and man. This desire to rationalize supernatural is typical of the highest forms of gnosticism. The utopia of socialist realism inherits the basic thesis of the gnostic religion about hostility of the substance of the very essence of "real man", its liberation from all the conventions and cultural norms (Heller, 2007, 165-183). Reality that opposes to revolutionary will is considered as "erroneous" and sacrificed to the unknowable Absolute - communism, which in literature is described apophatically or on default (mystical images of fairyland Dair, blue cities and ocean). The significance of what is happening comes down to the constant replacement of absence by presence, and in this sense social realism belongs to the same semantic paradigm as gnosticism, the European theater of the absurd and existentialism (Smirnov, 1994). Archetypes of gnostic religion are absorbed by the culture of social realism with preservation of original mystical and religious content. Ideas and images of the "Brotherhood of devoted", mystical "call", "knowledge" and "sparkle" take the place of Christian symbolism and participate in its rethinking.

In the second half of the 1930s, the utopian model of Soviet society that is traditionally correlated with the pyramid was finally formed. "Socialist nation" forms the basis of the pyramid with the Leader at the top. Representation of power "has nowhere been so completely represented as in the leader demonstration. Canonization and mythologizing of leaders and their glorification are included in the genetic code of the Soviet literature" (Dobrenko, 1993, 74). Within the frames of the Masonic myth "socialist nation" is functionally equated with a victim of formation. Elements of the gnostic mythogenesis are manifested at all the levels of formation of the socialist-realist model of the world:

- at the level of its spatio-temporal characteristics, organized through the traditional gnostic opposition of "'other"" - real", "the world of "communist gnosis" - profane world", "utopia - story"; 
- at the level of artistic images system, where the main role is allotted to the heromissionary who discovered the mystery of salvational "call" to the profane world;

- at the level of moral characteristics of the events, where assessments of heroescommunists, endowed with knowledge of the future are the dominant ones.

Reduction of the gnostic-utopian canon took place in the second half of the 1950-1970s. Agonizing canon becomes more strict and aggressive. Utopia loses the necessary totality, but it does not negate its power absolutely. Social realist models of the world have a strong force of inertia, which was proven by the practice of postmodernism (the direction of social art).

The next global utopian project in Russian literature of the second half of the $20^{\text {th }}$ century was the project of artists, the traditionalists in a variety of authors' variants. Several directions, labeled utopian intentions: the ideas of Slavophilism, Pochvennichestvo, and partly Eurasianism served as the philosophical basis. Several styles, marked by utopian intensions are accentuated in the traditionalist prose: hope in cyclical theory that was formed in the Ancient times and inevitability of the "golden age" repetition are combined with the Christian preaching of spiritual self-improvement and self-restraint of a person (society) on the way to the "new Russia" and attempts of reconciliation, contamination of Promethean utopia of the Bolshevism with the doctrines of orthodoxy (based on the similarities of austerity, sacrifice and transformed communality) - the style of neo Eurasianism (Kovtun 2009).

Under these conditions literature inherits churches and is compared to the pulpit, the author is assimilated to the prophet who simulates transition to the world of tradition. A carrier of the old faith", who preserved the features of the ascetic being, devotion to the precepts of ancestors and ability to resurrect them in the present days becomes the chosen hero of the patriarchal utopia. Originality of the worldview, recreated in the works by the "villagers", evolves the fact that the apocalyptic worldview of the present is combined with the utopian world of the "live past", presented as the lost ideal of the world order. Thus, "village prose" is essentially monologic and appeals to the restoration of the same hierarchical worldview, but, on the other basis. God-bearing people are at the top of the pyramid of values, and their confession was depicted by "retentive literature". Traditional metagenre trends are clearly detected in the patriarchal utopia creation: the image of perfect Russia is revealed in the opposition to "alien" lands (modern Russia here is also "alien"); it is distanced from the "diabolical civilization" in space and time. Revelation of the Absolute is given in the mystical form (a dream, a vision, a memory, a tale) and disclosed to the chosen ones writers-prophets. Rational progressivist utopia is challenged from the perspective of another utopia, based upon archaic myth (Kovtun, 2011, 280-311).

Intellectual situation of the turn of the $20^{\text {th }}-21^{\text {st }}$ centuries indicated that the hopes for the revival of Russia as a peasants' state are not destined to come true. The "Radiant future", which Russian progressives and traditionalists followed by the directly opposite ways, was gone. The modern Russia, deprived of protection of Utopia, was thrown into the crossroads of real history, and in this position of God's fool under a fence, it was described by the postmodern literature.

\section{Resume}

Thus, the analysis of Russian literary utopia of the second half of the $20^{\text {th }}$ century has confirmed imperishable interest of modernity to utopian metagenre. Modern utopia changes in its form ("spatial myths" actualization, "openness" of the text, dynamism, unexpressedness of the 
metagenre criteria) and in its essence (emphasis on the internal state of a hero, psychologism, philosophicity, including the conflict into a vision of the future), but always presents in the human mind. Its relevance in the modern world that has exhausted purely materialist conception of personality and history, remains unchanged. In the situation of ideological chaos the value of the known forms of reality understanding increases, as evidenced by creativity of the traditionalists'. Utopia becomes one of the ways of survival in history.

The leading feature of the modern Russian utopia, except esotericism and messianism is literal nature of its claims to change history, the world and man. The boundary between text and reality is lost. Intellectual projects of reorganization of being created by utopianistsclassics turned into a direct guidance for action in the interpretation of the avant-garde with its idea of the art of life-building. Change of utopian perspective (from theory to practice) required a fundamentally different scale of values, where the previous morality, compassion and fellowship would turn out to be insignificant. The new era in the history of utopia is signified by the name of A. Bogdanov, who proclaimed the immoralist, the proletarian that gives rich in opportunities for "cultivation" of ideas, the ideal hero of the Russian artistic cosmos. The man from the crown of creation is transformed into an auxiliary material that from now signifies its value. The Leader, the Great Shaman, the Martian, "sent" to the "sinful" Earth from the outside is at the top of the utopian pyramid. The idea of utopia acquires the character of expansion, where Russian people turn out to be Aboriginal people. The social-realist utopia in which language the mystical baggage of the previous utopian tradition is changed into the pragmatic channel, will move in the given direction.
The traditionalists-writers, for the same purposes of transformation and "purification" of the Holy Russia offered another way of going back to the origins, to the moral precepts of the Old Believers, they appeal to the evangelical prophecies, but utopia-"reconstruction" also lies at the heart of their artistic projects. Extension of the "village prose" to metaphysics, its appeal to the retrospective utopianism of the explicit type that puzzled criticism of the late 1970s, showed disappearance of the ground beneath them, when there is no longer space for self-realization, but only "mirage", futurist space of civilization.

In varying degrees, artistic utopias in Russia are involved in a dialogue with the utopia of the absolute state, losing novelty (novum) and are merged with the ideology. All the forms of utopianism (including artistic utopia) now either serve the state, or confront it (utopias by A. Solzhenitsyn and the dissidents), and then retain the explicit or implicit dependence on it. Sectarians' utopias, built on the principle of anachronism and "escape" from the world partly comprise exclusion. This practice of isolationism allowed writers-traditionalists to appeal to the authority of the Old Believers as an expression of "purity" and righteousness of the original Russia, which commandments should be revived in the critical modernity.

The process of overcoming utopian discourse in the literature of postmodern is not as straightforward. Debunked utopia of social realism that compromised the principle of the utopian world understanding itself, led to the displacement of artistic criteria in the phenomenon assessment as well. The title of writer-prophet was preferred to the position of "heretic", "frontiers" intruder and interpreter, but not a participant of utopian mystery. In such a way, reaction to utopia as a big and totalizing narrative appeared (Petrovskaya, 2013, 245-253). 
The central image of the world picture at the turn of $20^{\text {th }}-21^{\text {st }}$ centuries became a person of multitude, a representative of cultural periphery. Under the rubble of Utopias personality fell to pieces, crushed by the circumstances of chaos, and now "fragmentary", "garbage man" inevitably have to perform a mythological function. Postmodernist letter mythologizes both the world picture, and the nature of character, but the pathos of authorial myths is solved directly counter tradition: they do not perform their main function of harmonization. There is a lot of laughter in anti-utopias of the beginning of the 2000 s, but continuous horror shines through it. In utopias heroes went away, escaped from the power of Leviathan, antiutopias showed that there are no uninhabited islands any more, that state and its citizens have the only destiny - history: "Escape Hatch" by V. Makanin, "The New Robinson Crusoes" by L. Petrushevskaya, "Kys" by T. Tolstoy, etc. Character's fear of the authorities turned to the horror of state towards its own army, that can not read and write, and hence, insensitive to the former forms of temptation (Vorob'eva, 2006, 253).
Analysis of the Russian utopian tradition suggests that the desire to get rid of the previous legacy (utopias of avant-garde and social realism), to throw it "from the ship of modernity" and instantly, to reach the "paradise" "light" is replaced by nostalgia for the culture and national traditions (the "villagers" utopia). However, the return from eternity to time discovers "poverty" of the present ("ludic" meta-utopias of postmodernism), in which there is no place for the ideal and gives rise to a new desire to go over the edge to the "different" future. It is obvious that in the nearest period as well eschatological moods and eschatological problematics in literature will be its distinctive marks, and, therefore, new utopian versions of a better tomorrow will be created.

Duality of attitude towards utopia was the result of failure to distinguish utopia as fictional text and "extra-textual reality" what led to absolutization and mythologizing of both. This situation of denial, profanation of utopia and a distinct "melancholy" for it is one of the constants of the modern culture that is indicative of the impossibility to imagine Russia and the world out of utopian horizon.

Utopia is understood as metagenre, "tertiary genre", according to M.M. Bakhtin's terminology, into which any "secondary" genre is built in: utopic novel, story or narration

\section{References}

1. Akimov, V.M. (1994) Ot Bloka do Solzhenitsyna. Sud'by russkoi literatury dvadtsatogo veka (posle 1917 goda) [From Blok to Solzhenitsyn. Destinies of Russian Literature of the $20^{\text {th }}$ Century (after 1917)]. SPb.: Saint-Petersburg State Academy of Culture. 164 p.

2. Artem'eva, T. (2005) Ot slavnogo proshlogo k svetlomu budushchemu. Filosophiia istorii i utopia v Rossii epochi Prosveshcheniia [From Glorious Past to Better Future. Philosophy of History and Utopia in Russia of the Age of Enlightenment]. SPb.: Aleteia, 2005. 496 p.

3. Artem'eva, T. (2000) Utopicheskie arkhetipy v russkoi kul'ture [Utopic Archetypes in Russian Culture]. Age of Philosophy: Almanac. Iss.13: Russian Utopia of the Age of Enlightenment and Traditions of the World Utopianism. SPb. Pp. 16-25.

4. Bellamy E. (1893) Cherez sto let (Zvgliad Nazad) [Looking Backward]. SPb.

5. Berdyaev, N. (1994) Russkaia ideia. Osnovnye problemy russkoi mysli XIX veka i nachala XX veka [Russian Idea. The Main Problems of the Russian Thouht of the $19^{\text {th }}$ Century and the Early 
$20^{\text {th }}$ Century]. Russian Idea. Among Writers and Thinkers of the Russian Expatriate Community: In 2 Volumes. M.: Iskusstvo. Vol. 2. Pp. 204-286.

6. Bourdieu P. (1998) Struktura, gabitus, praktika [Structure, Habitus, Practice] [Available at], Journal of Sociology and Social Anthropology.Vol. I. № 2. URL: http://www.jourssa.ru/1998/2/4 bourd.html (accessed: 09.11.2014).

7. Bushmin, A.S. (1980-1983) M.E. Saltykov-Shchedrin [E. Saltykov-Shchedrin]. History of Russian History: In 4Volumes. Leningrad. Vol. 3. 880 p.

8. Vaiskopf, M. (2003) Ptitsa-troika i kolesnitsa russkoi dushi. Raboty 1978-2003 godov [Trioka-bird and the Chariot of Russian Soul. Works of 1978-2003]. M.: Novoe Literaturnoe Obozrenie. 576 p.

9. Vernadsky, G.V. (1917) Russkoe masonstvo v tsarstvovanie Ekateriny II [Russian Masonry During Reign of Catherine the Great]. Pg.: Tip. Akts. O-va Tip. Dela v Petrograde.. XXIV. 285 p.

10. Vorob'eva, A.N. (2006) Russkaia anti-utopiia XX veka v blizhnikh i dal'nikh kontekstakh [Russian Anti-Utopia of the $20^{\text {th }}$ Century in Close and Extended Contexts]. Samara: Samara Scientific Centre of RAS Publishing House. 268 p.

11. Heller, L. (2007) Topika zveria i topika novogo cheloveka, ili vopros ob oborotne [The Topic of Beast and the Topic of New Man, or the Issue of Werewolf]. Utopia of Animality. Representation of Animals in Russian Culture. Ed. by L. Heller. Lausanne- Drohobych: Kolo. Pp. 165-183.

12. Heller, L., Nike, M. (2003) Utopia v Rossii [Utopia in Russia]: Transl. from French by I.V. Bulatovsky. SPb.: Giperion. 312 p.

13. Herzen, A.I. (1963) Sobranie Sochinenii [Collected Works]: In 30 Vol. M., Vol. 19. Book. 1.

14. Goldstein, A. (1997) Rasstavanie s nartsissom. Opyty pominal'noi ritotiki [Parting with Narcissus. Experiences of Commemorative Rhetoric]. M.: Novoe Literaturnoe Obozrenie. 448 p.

15. Groys, B. (1993) Utopia i obmen. Stil' Stalin. O novom [Utopia and Exchange. Stalin Style. About the New]. M.: “Znak" Publishing House. 375 p.

16. Debagory-Mokrievich, V.K. (1989) Avtobiographiia [Autobiography]. Representatives of the USSR and Revolutionary Movement in Russia: Encyclopedic Dictionary Granat. M., Pp. 57-105.

17. Dobrenko E. (1993) Metaphora vlasti. Literatura stalinskoi epokhi v istoricheskom osveshchenii [Power Metaphor. Literature of Stalin Era in Historical Interpretation]. Munich. 408 p.

18. Egorov, B.F. (1985) Ob osobennostiakh russkikh sotsial'nykh utopii 1840-kh godov [On Special Aspects of the Social Utopias of the 1840s]. Problems of Cultural Heritage Study. M. Pp. 257-260.

19. Egorov, B.F. (2007) Rossiiskie utopii: Istoricheskii putevoditel' [Russian Utopias: Historical Guidebook]. SPb.: Iskusstvo - SPb., 416 p.

20. Kazarkin, A.P. (2001) Russkaia literatura i philosohpiia Serebrianogo veka [Russian Literature and Philosophy of the Silver Age]. Tomsk: TSU, 2001. 54 p.

21. Kalinin, I.A. (2002) Russkaia literaturnaia utopia XVIII-XX vekov: problemy poetiki i philosophii zhanra [Russian Literary Utopia of the $18^{\text {th }}-20^{\text {th }}$ Centuries: Problems of Poetics and Genre Philosophy. Author's Abstract of the Thesis of Candidate of Philology. Spb.

22. Kasatkina, T.A. (1996) Phantazia na temu biographii F.M. Dostoevskogo [Fantasia on F.M. Dostoevsky's Biography]. Dostoevsky and Modernity: The $10^{\text {th }}$ International Old Russian Readings Proceedings of 1995. Novgorod State Museum-Reserve. F.M. Dostoevsky's House-Museum. Staraia Russa: [b. i.]. 
23. Clark, K. (2002) Sovetskii roman: istoria kak ritual [Russian Novel: Story as a Ritual]: Tr. From English Edited by M.A. Litovskaia. Ekaterinburg: Ural University Publishing House. $262 \mathrm{p}$.

24. Kovtun, N.V. (2009) Derevenskaia proza v zerkale utopii ["Village Prose" in the Mirror of Utopia]. Novosibirks: SB RAS, 2009. 494 p.

25. Kovtun, N.V. (2011) Idillicheskii chelovek na perekrestkakh istorii: po proizvedeniiam A. Solzhenitsyna, V. Rasputina, B. Ekimova, L. Petrushevskoi [Idyllic Man at the Crossroads of History: on the Works by A. Solzhenitsyn, V. Rasputin, B. Yakimov, L. Petrushvskaya]. Russian Project of the World Reconstruction and Artistic Creativity of the $19^{\text {th }}-20^{\text {th }}$ Centuries. Monograph. Edited by N.V. Kovtun.. M.: Flinta: Nauka, 2011. Pp. 280-311.

26. Kovtun, N.V. (2010) Ideia "zemnogo raia" v povesti A.E. Novoselova "Belovodie" [The Idea of Earthly Paradise in the Story by A.E. Novoselov "Belovodie"]. Siberian Text in the National Plot Space. Monograph. Krasnoyarsk: SFU. Pp. 133-144.

27. Kovtun, N.V. (2005) Russkaia literaturnaia utopia vtoroi poloviny XX veka [Russian Literary Utopia of the Second Half of the $20^{\text {th }}$ Century]. Monograph. Tomsk: TSU. 536 p.

28. Kovtun, N.V., Proskurina, E., Vasil'ev I. (2013) Proekt pereustroistva mira i russkaia proza nachala XX veka (A. Bogdanov, A. Platonov) [The Project of the World Reconstruction and Russian Prose of the Early $20^{\text {th }}$ Century (A. Bogdanov, A. Platonov)]. Siberian Philological Journal. №2. Pp. 129-140.

29. Lotman, Y.M. (1994) Besedy o russkoi kul'ture. Byt i traditsii russkogo dvorianstva (XVIII nachalo XIX veka) [Talks About Russian Culture. Everyday Life and Traditions of Russian Nobility (the $18^{\text {th }}-$ Early $19^{\text {th }}$ Centuries)]. Iskusstvo-SPb., $399 \mathrm{p}$.

30. Manheim, K. (1994) Diagnoz nashego vremeni [Diagnosis of Our Time]: Tr. From English by M.I. Levina at al. M.: Nauka.

31. Matich, O. (2008) Eroticheskaia utopia: novoe religioznoe soznanie i fin de siecle v Rosii [Erotic Utopia: The Decadent Imagination in Russia's Fin de Siècle]. M.: Novoe Literaturnoe Obozrenie, $400 \mathrm{p}$.

32. Mil'don, V. (2006) Sanskrit vo l'dakh, ili vozvrashchenie iz Ophira [Sanskrit in Ice, or Return From Ophir]. M., 2006. 288 p.

33. Mitin, G. Ot real'nosti k miphy (Zametki o genezise i funktsionirovanii sotsrealizma) [From Reality to Myth (Notes on Genesis and Social Realism Functioning)]. Issues of Literature. № 4. Pp. 24-53.

34. Mogil'ner, M. (1999) Miphologia podpol'nogo chelovaka [Mythologization of Underground Man]. M.: Novoe Literaturnoe Obozrenie. 208 p.

35. Morton, A. (1956) Angliiskaia utopia [English Utopia]: Tr. From English by O.V. Volkova. Edited and with Introduction by V.F. Semenov. M.: Izd-vo inostr. lit., 278 p.

36. Editorial Note (2014). Krizis literaturotsentrism: utrata identichnosti vs. novye vozmozhnosti [Literary Centrism Crisis: Loss of Identity vs. New Opportunities]. Monograph. Ed. in ChiefN. Kovtun. M.: Flinta-Nauka. Pp. 5-9.

37. Pavlova, O.A. (2004) Russkaia literaturnaia utopia 1990-1920kh godov v kontekste otechestvennoi kul'tury [Russian Literary Utopia of the 1900-1920s in the Context of Russian Culture]. Volgograd. 
38. Paperno, I. (1996) Semiotika povedeniia: Nikolai Chernyshevsky - chelovek epokhi realizma [The Semiotics of Behaviour: Nikolai Chernyshevskyand the Age of Realism]: Tr. From English by T.Y. Kazachinsky. M.: Novoe Literaturnoe Obozrenie. 207 p.

39. Parthe, K. Russkaia derevenskaia proza: Svetloe proshloe [Russian Village Prose: The Radiant Past] (2004): Tr. From English by I. Chekannikova and E. Kirilova.Tomsk: TSU. 204 p.

40. Petrovskaya, E. (2013) Utopicheskoe v massovoi kul'ture [Utopic in the Mass Culture]. Russian Utopia in the Context of the World Culture. SPb.: Aleteia, 2013. Pp. 245-253.

41. Petrucciani, A. (1991) Vymysel i pouchenie [Fiction and Homily]. Utopia and Utopian Thinking. M.: Progress. P. 98-112.

42. Pushkin A.S. (1986) Sochineniia [Works]: In 3 Vol. M., Vol. 2.

43. Pushchin, L. (Z. Gippius) (1898-1908) Literaturnyi dnevnik [Literary Diary]: Collection of Literary Reviews. SPb., Iss. III. Obratnaia Religiia.

44. Sakharov, V.I. (2000) Masonstvo, literatura i izotericheskaia traditsiia v vek Prosveshcheniia [Freemasonry, Literature and Esoteric Tradition at the Age of Enlightenment]. Freemasonry and Russian Literature of Russian Literature of the $18^{\text {th }}$ - Early $19^{\text {th }}$ Centuries. M.: Editorial URSS. 272 p.

45. Severnaia pchela [Northern Bee]. 1851. 14 April.

46. Semevsky, V (1909) Politicheskie i obshchestvennye idei dekabristov [Political and Social Ideas of the Decembrists]. SPb.: Tip. 1-oi SPb. Trud. Arteli. 12. 694 p.

47. Svirsky, V.D. (1992) Demonologiia [Demonology]. Riga.

48. Smirnov, I.P. (1994) Psikhodiakhronologika. Psikhoistoriia russkoi literatury ot romantizma do nashikh dnei [Phycodiachronologics. Psychohistory of the Russian Literature from Romanticism up to Present Days]. M.: Novoe Literaturnoe Obozrenie. 352 p.

49. Frank, S. (1990) Sochineniia [Works]. M.: Pravda.

50. Khlodovsky R.I. (1999) Pushkin i Petrarka: gumannost' Pushkina [Pushkin and Petrarca: Pushkin’s Humanism]. Journal of RHSF. № 1. Pp. 308-316.

51. Chayanov, A.V. (1989) Venetsianskoe Zerkalo. Povesti. [The Venetian Mirror. Stories]. M.: Sovremennik. 235 p.

52. Chertkova, E. (1993) Utopia kak tip soznaniia [Utopia as a Type of Consciousness]. Social Sciences and Modernity. № 3.

53. Chistov, K.V. (1967) Russkie narodnye sotsial'no-utopicheskie legendy XVII-XIX vv. [Russian Folk Social-Utopian Legends of the $17^{\text {th }}-19$ th]. M. 341 p.

54. Shcherbatov, M.M. (1896-1898) Sochineniia kniazia M.M. Shcherbatova [Works by Prince of M.M. Shcherbatov]: In 2 Vol. SPb., Vol.1.

55. Etkind, A. (2001) Tolkovanie puteshestvii. Rossiia i Amerika v travelogakh i intertekstakh [Interpretation of Travels. Russia and the US in Travelogues and Intertexts]. M.: Novoe Literaturnoe Obozrenie. 496 p.

56. Etkind, A. (1998) Kklyst: (Sekty, literatura i revolutsiia) [Khlyst: (Sects, Literature and Revolution)]. M.: Novoe Literaturnoe Obozrenie. 688 p.

57. Levitas R. Utopia as Method: The Imaginary Reconstitution of Society. University of Bristol, UK. 2013. 270 p.

58. Rossi Varese, M. (1981) Utopisti russi del Primo Ottocento. Napoli. 
59. Mumford, L. (1972) The Story of Utopies. New York.

60. Webb, S. (1980) The Harmonious Circle: The Lives und Work of G.I. Gurdjjeff, P.D. Ouspensky und Their Followers. London.

\title{
Политический дискурс
}

и художественный вымысел

в изображении утопической действительности

\author{
Н.В. Ковтун, В.В. Ковтун \\ Сибирский федеральный университет \\ Россия, 660041, Красноярск, пр. Свободный, 79
}

\begin{abstract}
В российских и западных литературных исследованиях особенность русской культуры часто рассматривают через призму утопии. В данной работе прослеживается формирование утопического метажанра в отечественной словесности, показана смена акцентов с политического дискурса на беллетристику, анализируются архетипы, отличающие утопическое моделирование в различные культурные эпохи. Возможно, для характеристики современной литературы и нет более емкого термина, чем «утопия», где утопии авангарда предваряют глобальную коммунистическую утопию, оформившуюся в художественном творчестве через теорию социалистического реализма, на смену которой в 1950-1960-е годы придёт ретроспективная утопия «деревенщиков» в разнообразии авторских вариантов и технократические утопии «молодёжной прозы». В данной парадигме место постмодернизма как совокупности практик противостояния утопическим интенциям определено ролью антиутопии.
\end{abstract}

Ключевые слова: утопия, антиутопия, утопический метажанр в российской беллетристике, политической беседе, утопическом моделировании мира.

Научная спещиальность: 10.00.00 - филологические науки. 